\title{
Study of Glass Tilt Angle to Achieve Optimum Overall Thermal Transfer Value (OTTV)
}

\author{
Wiyugo Hari Pranoto ${ }^{1}$, Jatmika Adi \\ Suryabrata ${ }^{2}$, M. Santosa ${ }^{2}$ \\ 1 Student of the Master of Architecture, Department of Architecture and \\ Planning, Universitas Gajah Mada \\ ${ }^{2}$ Lecturer of the Master of Architecture, Department of Architecture and \\ Planning, Universitas Gajah Mada
}

\begin{abstract}
Glass Reflectance is the ability of the glass surface to reflect light when passing through the glass surface. All types of glass have this capability (Clear Glass, Tinted Glass, and Reflective Glass). With its ability, not all the light will be passed through the glass because the glass surface will reflect some of the light. The magnitude of reflection depends on the tilt angle of the glass against the light direction. It means if the glass is applied to the building façade and exposed to sunlight, not all sunlight and the heat forwarded into the building. To know the exact tilt angle of the glass when applied to the building, research on the effectiveness of light reflection by the tilt angle of the glass is necessary. This research uses a computer simulation method with hypothetical building objects. This research aims to test how effective the tilt angle of glass reflects the sunlight when applied as the building facade. The tilt angle tested in the simulation is a tilted and rotated glass. The tilt angle effect of the glass can be calculated using the building's OTTV (Overall Thermal Transfer Value).
\end{abstract}

Keywords: tilt angle glass, OTTV, simulation

\section{Introduction}

The world's energy consumption continues to increase the risk of a global energy crisis. Nowadays, the building sector consumes 40 percent of the total global energy. It is predicted, in the next 2040, the entire world energy consumption for buildings will increase by 80 percent (Ramadhiani, 2017).

The most significant energy consumption in buildings is in the air conditioning system. The air conditioning system is used to cool the air in a hot room to be comfortable when inhabited by humans. The air in the room gets hot because of the sun rays, and the heat goes into the building. By minimizing the heat entering the building, the use of energy for air conditioner can become more efficient. Thus, the less

Correspondence: Wiyugo Hari Pranoto

Student of the Master of Architecture, Department of

Architecture and Planning, Universitas Gajah Mada

E-mail: wiyugo.hp8@gmail.com energy used in buildings will eventually reduce world energy consumption.

\section{Literatur Review}

Along with the changing times and technological advancements, the world's energy needs continue to increase, thus putting the world at risk of an energy crisis. Some of the factors increasing energy demand were the invention of a steam engine in 1764 by James Watt, and also the increasing population of the world. Although there are currently many alternative energy sources that are utilized to meet the world's energy needs, the energy crisis remains a threat. Many people predict that the world energy crisis will occur in the next 20 to 30 years.

\section{World Energy Consumption}

The world's largest energy source that humans use today is petroleum, where petroleum is a non-renewable energy source. With the 
increase in world energy consumption, the world oil reserves will decrease faster so that there was a world energy crisis (Elinur, Priyarsono, Tambunan, \& Firdaus, 2010). Energy-saving efforts from the building sector are needed to reduce the burden of world energy consumption.

\section{Building Energy Saving Efforts}

Efforts to save energy in buildings by designing energy-efficient buildings commonly referred to as green buildings. Vale (1991) states that there are several principles in green building planning, namely:

- Minimize the use of fuel or electricity in operational,

- Pay attention to the site climate conditions or location of the building, optimize the needs of natural resources,

- The utilization of natural resources,

- Do not harm the environment or site, and

- Does not negatively impact the health and comfort of building occupants, does not damage the site and the environment.

To be highlighted, energy savings in this case emphasize on the energy consumption when the building is operated or used.

\section{Building Energy Consumption}

The most significant energy consumption in the building is in the room air conditioning system. The heat load received by the building will affect the building cooling load (Kusumawati, L. \& Lahji, K., 2015). So that minimizing the heat entering the building can reduce building energy consumption. The heat load from outside the building comes from the radiation of sunlight entering through the building envelope. Building envelope consists of openings such as glass and building walls, heat that is delivered through glass has a higher value than the heat came through walls (Putri, Rohman, \& Utomo, 2012). So by minimizing the heat which enters through the glass, it will be more effective in reducing the heat load that must be cooled by the air conditioning system.

\section{Building Heat Source}

According to (Loekita 2006) the cooling load in the room is caused by (1) external heat load, namely heat from outside sources entering the building through the building envelope such as from radiation, solar conduction and infiltration and (2) internal heat load, namely heat generated by occupants, artificial lighting and equipment.

By minimizing the heat entering the building, the use of energy for air conditioning can be more efficient. Thus, energy use in buildings is reduced and is expected to reduce world energy consumption.

\section{Strategy to Reduce External Heat}

Strategy to reduce heat from outside the building, focusing on reducing or blocking the entry of sunlight into the building through the building envelope, thereby reducing the value of OTTV. The OTTV value reduction strategy is carried out in several ways, namely:

- reduce the area of building facade openings or WWR (Window to Wall Ratio) (Loekita 2006),

- regulate building orientation by avoiding openings in the west and east (Saud, 2013),

- use shading at building facade openings (Kusumawati \& Lahji 2015; Readitya, 2013; Sunusi, 2016).

Efforts to reduce solar heat can also be improved by looking at the specifications of glass used, such as solar absorption, solar transmittance, solar reflectance, SHGC (Solar Heat Gain Coefficient), and Solar Factor.

Out of the five specifications, solar reflectance has the potential to reduce solar heat entering the building, which not much research has done before. Solar reflectance is the ability of glass to reflect sunlight. Generally, the type of glass used for building facades is the type of clear glass, tinted glass, and reflective glass, each of which can reflect different sunlight.

\section{Research Methods}

This research uses a quantitative deductive method by modeling objects and simulations with the help of computer software. The use of simulation methods is chosen to avoid the difficulty of direct research on real object. In the study, a box-shaped building with a Window to Wall Ratio of $70 \%$ glass openings is needed, which faces north, east, south, and west. Buildings with these specifications are required to measure the amount of solar radiation entering the building through the glass of all orientations. Measurements were carried out for one year in Jakarta. The city of Jakarta was chosen because there are many buildings with glass facades, both high rise and low rise 
buildings.

The simulation method is used in experiments using computer software to produce predictions without conducting experiments directly. This method uses a replica (model) in a real-world context, which is controlled (manipulated) to study the interaction between the model's manipulated factors. In this case, the interaction between the building model and the simulated object location weather data. This interaction is a reflection of interactions that occur in the real world, and the simulation method is the only method that can produce data related to these interactions to be applied to the real-world context (Groat \& Wang, 2002).

\section{Research Instruments}

EnergyPlus software is claimed to have advantages related to sensitivity and validity from the results of the simulation (Pereiraa, Bögla \& Natschlägera, 2014). Therefore, the software used in this research is SketchUp and OpenStudio as a modeling tool, EnergyPlus as a simulation tool and data input, and Microsoft Office to recap and process simulation data.

\section{Locus and Research Focus}

The object of research is a hypothetical building with many floors and functions as office in Jakarta. The office building that was taken was a multi-story building with a glass facade (curtain wall). This building was chosen because many office buildings today are quite dominant in Jakarta. Most of these buildings have an entire glass facade or commonly called a curtain wall. This type of facade has a wide opening and allows the entry of hot sunlight into the room in large quantity.

\section{Building Geometry}

The research room in the form of a multi-story office is assumed to be a zone with a size of $10 \times 10 \mathrm{~m}$ with a height of floor zone, floor to ceiling $3 \mathrm{~m}$, and height of a plenum zone of 1.2 $\mathrm{m}$, Floor to floor height of $4.2 \mathrm{~m}$.

Figure 1. Building Geometry

Source: Author

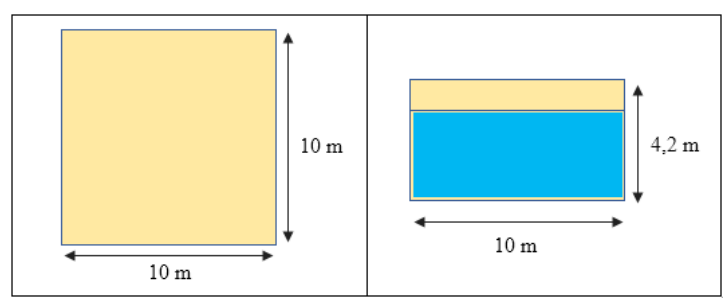

\section{Research Variable}

The independent variables in this study are:

- Glass type

The type of glass used in this study is the type of clear glass, the type of tinted glass, and the type of reflective glass or glass that has a coating that looks like a mirror. The glass is as in the following table.

Table 1. Glass Type Variable

\begin{tabular}{lccl}
\hline Name & SHGC & $\begin{array}{l}\text { Thickness } \\
(\mathbf{m m})\end{array}$ & $\begin{array}{l}\text { Solar } \\
\text { Reflectance }\end{array}$ \\
\hline Indoflot Clear & 0.774 & 8 & 0.062 \\
$\begin{array}{l}\text { Panasap } \\
\text { DarkBlue }\end{array}$ & 0.533 & 8 & 0.048 \\
$\begin{array}{l}\text { Stopsol } \\
\begin{array}{l}\text { Supersilver } \\
\text { Dark Blue }\end{array}\end{array}$ & 0.427 & 8 & 0.218 \\
\hline
\end{tabular}

\section{- Glass tilt angle}

The glass that is applied as a building facade is inclined downward-facing to the tilt with a slope starting from perpendicular to the horizontal ground, then $0^{\circ}, 5^{\circ}, 10^{\circ}, 15^{\circ}$, $20^{\circ}, 25^{\circ}, 30^{\circ}, 35^{\circ}, 40^{\circ}, 45^{\circ}, 50^{\circ}, 55^{\circ}$, and $60^{\circ}$ to horizontal soil.

Figure 2. The slope of the skewed glass facade Source: Author

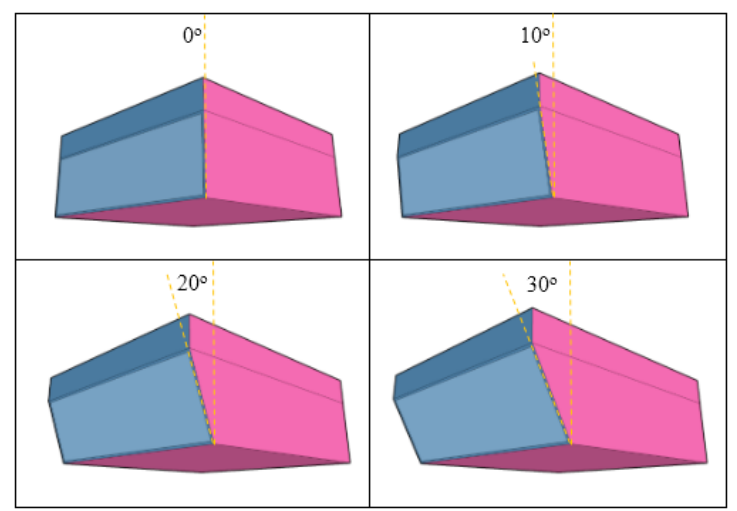

Then the glass in an upright position is also rotated starting from $5^{\circ}, 10^{\circ}, 15^{\circ}, 20^{\circ}, 25^{\circ}, 30^{\circ}$, $35^{\circ}, 40^{\circ}, 45^{\circ}$ in a clockwise direction and $5^{\circ}, 10^{\circ}$, $15^{\circ}, 20^{\circ}, 25^{\circ}, 30^{\circ}, 35^{\circ}, 40^{\circ}, 45^{\circ}$ counterclockwise direction.

\section{- Glass orientation}

There are four glass orientations for building facades, namely north, east, south, and west. 
Figure 3. Rotated glass facade Source: Author

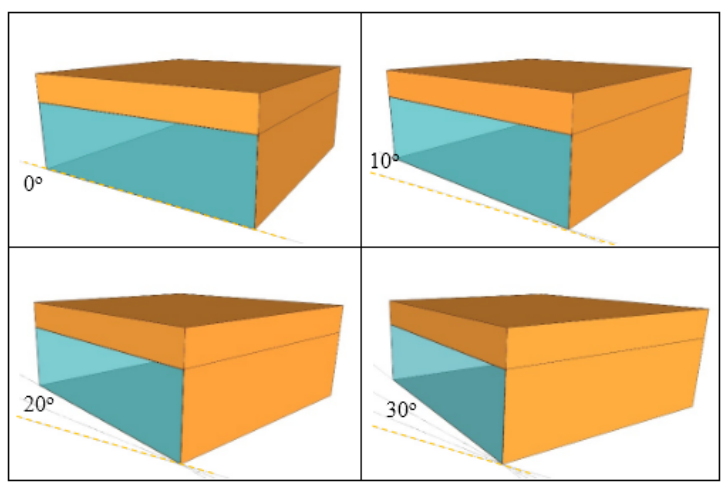

The inclined glass has the potential to influence the decrease in sunlight radiation that passes through the glass (Kirankumar \& Setty, 2015). The higher the tilt angle, the more significant the decrease in sunlight radiation passing through the glass. Therefore, a simulation is carried out to prove whether EnergyPlus can carry out these calculations. EnergyPlus must be able to show results that are close to or equal to the results of the study. The simulation is carried out in two stages:

- The first simulation, looking for the angle of sunlight coming perpendicular to the facade of the building located in Jakarta. The method used is to simulate hypothetical buildings in Jakarta with Jakarta weather data for one year and look for the hottest month, then look for the hottest day of the month. Then from that day, the hottest hour or time of the sun was found at 16:00 on 9 November.

- The second simulation calculates with EnergyPlus on that date and time. Calculations are made to calculate the effect of the slope of the glass on sunlight. As a result, EnergyPlus can do these calculations, as shown in the graph below.

Figure 4. EnergyPlus calculation results Source: author

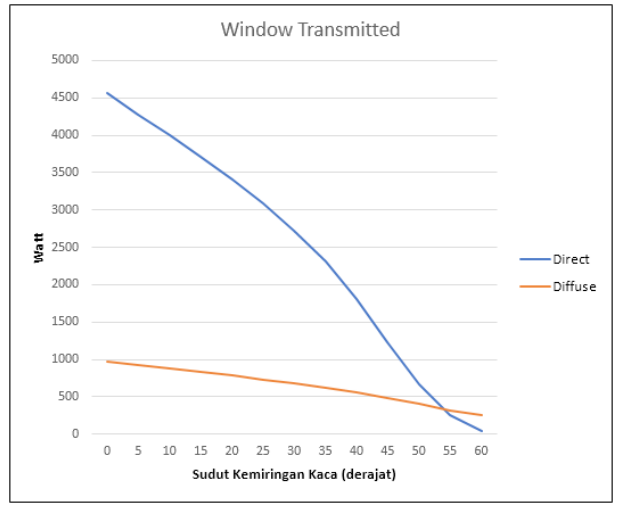

The picture above shows a decrease in sunlight radiation passing through the glass with an increasing inclination angle of the glass. Thus it can be concluded that EnergyPlus can carry out calculations related to the slope of the glass and give the result that the tilted glass affects the sun's rays transmitted by the glass. Visible decrease in light transmitted both from direct sunlight and diffuse sunlight.

\section{Simulation Stage}

The simulation is done in stages to match the expected results.

- Firstly, the simulation is carried out using a hypothetical building model that is fitted with clear glass, tinted glass, and reflective glass. Then the three glasses are inclined to the ground starting from $0^{\circ}, 5^{\circ}, 10^{\circ}, 15^{\circ}$, $20^{\circ}, 25^{\circ}, 30^{\circ}, 35^{\circ}, 40^{\circ}, 45^{\circ}, 50^{\circ}, 55^{\circ}$, and $60^{\circ}$ in the four building orientations. Then the OTTV values of each glass and each angle were calculated.

Figure 5. Model with the glass inclined $45^{\circ}$ west Source: author

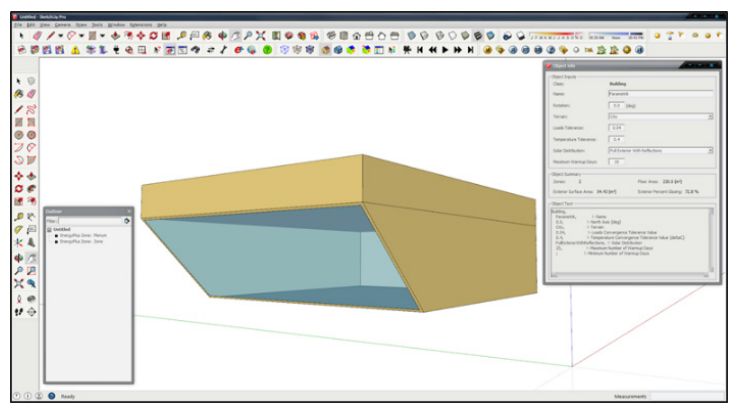

- In the second simulation, the simulation is carried out using a hypothetical building model mounted on clear glass. Then the three glasses are rotated starting from $0^{\circ}$, $5^{\circ}, 10^{\circ}, 15^{\circ}, 20^{\circ}, 25^{\circ}, 30^{\circ}, 35^{\circ}, 40^{\circ}$, and $45^{\circ}$ clockwise and $0^{\circ}, 5^{\circ}, 10^{\circ}, 15^{\circ}, 20^{\circ}, 25^{\circ}, 30^{\circ}$, $35^{\circ}, 40^{\circ}$, and $45^{\circ}$ counterclockwise, in all four building orientations. Then the OTTV values of each glass and each angle were calculated. 
Figure 6. Model with rotated glass $45^{\circ}$ west Source: Author

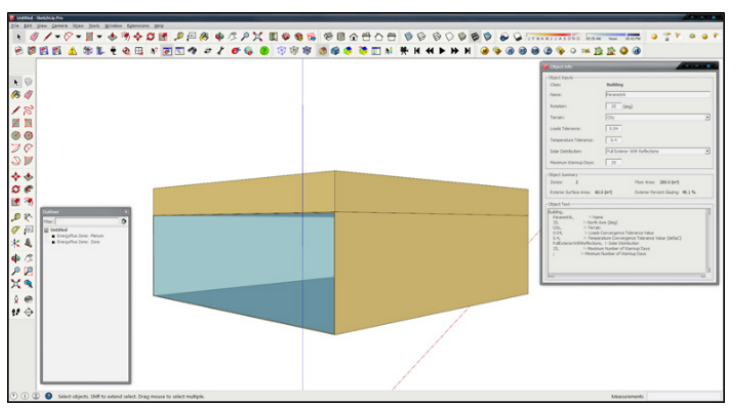

- In the third simulation, the simulation is carried out using a hypothetical building model mounted on clear glass. Then the building is given a shading or facade shading element along with the plenum formed by inclining the glass against the ground. This simulation is done as a comparison. Besides, it is also to find out whether the decrease in OTTV value in the room is affected by the reflection of the glass or because of the shading effect of the plenum that is formed when tilting the glass. For example, a slope angle of 150 will form a plenum along $109 \mathrm{~cm}$.

Figure 7. Model with $109 \mathrm{~cm}$ in the west direction Source: Author

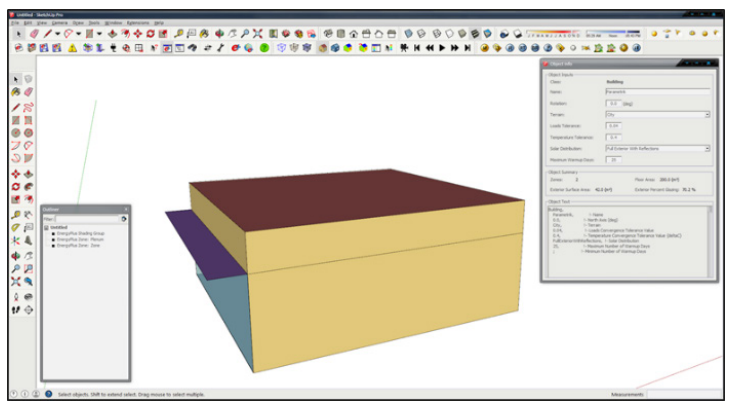

\section{Result and Discussion}

\section{The Slope of the Glass with the Facade Leaned}

The simulation is carried out by inclining the building's glass facade against the ground from $0^{\circ}, 5^{\circ}, 10^{\circ}, 15^{\circ}, 20^{\circ}, 25^{\circ}, 30^{\circ}, 35^{\circ}, 40^{\circ}, 45^{\circ}, 50^{\circ}$, $55^{\circ}$, and $60^{\circ}$ in the four building orientations. The results of OTTV calculations using EnergyPlus are as follows:

- Calculation result for Clear glass type (Indoflot Clear, thickness 8mm)
Figure 8. Calculation Result Indoflot Clear Source: Author

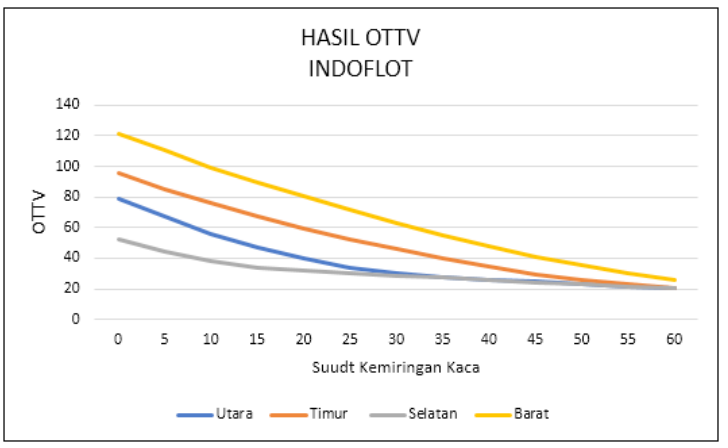

From the picture above, it can be concluded that:

1. The slope glass type of clear in the western orientation causes a decrease in the value of OTTV, which is almost directly proportional to the increase in the slope of the glass. There is a decrease in the value of OTTV by $\pm 8 \%$ for each addition of $5^{\circ}$ glass inclination.

2. Likewise, with the east orientation, there is a decrease in the value of OTTV, which is almost directly proportional to the increasing slope of the glass. There is a decrease in the value of OTTV by $\pm 8 \%$ for each addition of $5^{\circ}$ glass inclination.

3. For the north orientation, the decrease occurs is directly proportional and significant in the slope of $0^{\circ}$ to $25^{\circ}$, the value of the decline can reach $57 \%$. There is a decrease in the value of OTTV by $\pm 11 \%$ for each addition of $5^{\circ}$ glass inclination. The rest is less significant, only about $2 \%$ for every 5 degrees increment.

4. Whereas in the southern orientation, the decrease occurred significantly only in the slope of $0^{\circ}$ to $15^{\circ}$, the value of the decline reached $35 \%$. There is a decrease in the value of OTTV by $\pm 10 \%$ for each addition of $5^{\circ}$ glass inclination. The rest is less significant, only about 3\% for every 5 degrees increment.

5. The addition of the slope on the north and south sides shows a considerable decrease compared to the east and west sides. But basically, the value of OTTV on the north and south sides is already lower than the west and east sides. Facade slope up to $20^{\circ}$ on the west side is needed to obtain OTTV values equivalent to the north side in the upright position of $0^{\circ}$ and slope up to $40^{\circ}$ to obtain OTTV values on the south side equivalent of the vertical position of $0^{\circ}$. Whereas for the east side a facade slope up to $10^{\circ}$ is required 
Study of Glass Tilt Angle to Achieve Optimum Overall Thermal Transfer Value (OTTV)

Wiyugo Hari Pranoto, Jatmika Adi Suryabrata, M. Santosa

to obtain an OTTV value equivalent to the north side in an upright position of $0^{\circ}$ and a slope of up to $25^{\circ}$ to obtain an OTTV value equal to the south side in an upright position of $0^{\circ}$ (without being tilted/inclined).

6. Clear glass calculation results show a decrease in the value of OTTV for all orientations with the addition of the degree slope of the glass facade.

- Calculation of Tinted Glass (Panasap Dark Blue, thickness $8 \mathrm{~mm}$ )

Figure 9. Calculation Result of Panasap Dark Blue Source: Author

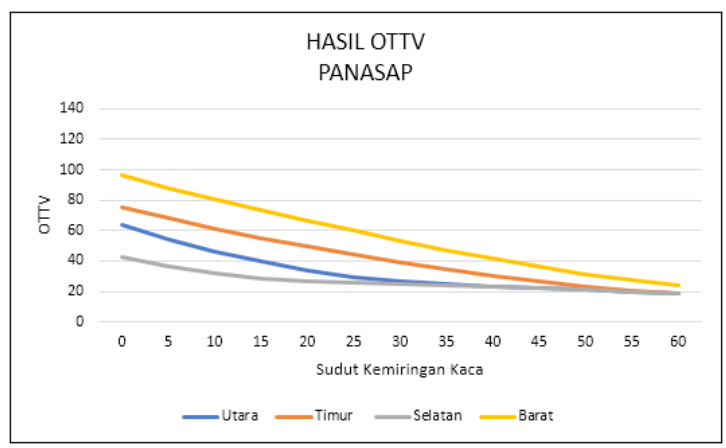

From the picture above, it can be concluded that:

1. The slope glass type of tinted in the western orientation causes a decrease in the value of OTTV, which is almost directly proportional to the increase in the slope of the glass. There is a decrease in the value of OTTV by $\pm 8 \%$ for each addition of $5^{\circ}$ glass inclination.

2. Likewise, with the east orientation, there is a decrease in the value of OTTV, which is almost directly proportional to the increasing slope of the glass. There is a decrease in the value of OTTV by $\pm 9 \%$ for each addition of $5^{\circ}$ glass inclination.

3. For the north orientation, the decrease occurs is directly proportional and significant when in the slope of $0^{\circ}$ to $25^{\circ}$, the value of the decline can reach $54 \%$. There is a decrease in the value of OTTV by $\pm 12 \%$ for each addition of $5^{\circ}$ glass inclination. The rest is less significant, only about $2 \%$ for every 5 degrees increment.

4. Whereas in the southern orientation, the decrease occurred significantly only in the slope of $0^{\circ}$ to $15^{\circ}$, the value of the decline reached $32 \%$. There is a decrease in the value of OTTV by $\pm 9 \%$ for each addition of $5^{\circ}$ glass inclination. The rest is less significant, only about $2 \%$ for every 5 degrees increment.
5. The addition of the slope on the north and south sides shows a considerable decrease compared to the east and west sides. But basically, the value of OTTV on the north and south sides is already lower than the west and east sides. Facade slope up to $23^{\circ}$ on the west side is needed to obtain OTTV values equivalent to the north side in the upright position of $0^{\circ}$ and slope up to $37^{\circ}$ to obtain OTTV values on the south side equivalent of the vertical position of $0^{\circ}$. Whereas for the east side a facade slope up to $10^{\circ}$ is required to obtain an OTTV value equivalent to the north side in an upright position of $0^{\circ}$ and a slope of up to $27^{\circ}$ to obtain an OTTV value equal to the south side in an upright position of $0^{\circ}$ (without being tilted/inclined).

6. Tinted glass calculation results show a decrease in the value of OTTV for all orientations with the addition of the degree of slope of the glass facade.

- Calculation of Reflective Glass (Stopsol Super Silver Dark Blue)

Figure 10. Result Calculation of Stopsol Super Silver Dark Blue

Source: Author

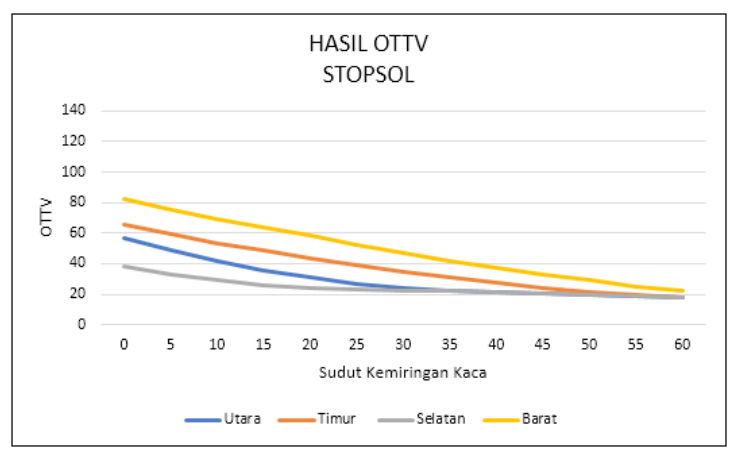

From the picture above, it can be concluded that:

1. The slope glass type of reflective in the west orientation causes a decrease in the value of OTTV, which is almost directly proportional to the increase in the slope of the glass. There is a decrease in the value of OTTV by $\pm 7 \%$ for each addition of $5^{\circ}$ glass inclination.

2. Likewise, with the east orientation, there is a decrease in the value of OTTV, which is almost directly proportional to the increasing slope of the glass. There is a decrease in the value of OTTV by $\pm 8 \%$ for each addition of $5^{\circ}$ glass inclination

3. For the north orientation, the decrease occurs is directly proportional and significant 
when in the slope of $0^{\circ}$ to $25^{\circ}$, the value of the decline can reach $53 \%$. There is a decrease in the value of OTTV by $\pm 11 \%$ for each addition of $5^{\circ}$ glass inclination. The rest is less significant, only about $2 \%$ for every 5 degrees increment.

4. Whereas in the southern orientation, the decrease occurred significantly only in the slope of $0^{\circ}$ to $15^{\circ}$, the value of the decline reached $33 \%$. There is a decrease in the value of OTTV by $\pm 9 \%$ for each addition of $5^{\circ}$ glass inclination. The rest is less significant, only about $2 \%$ for every 5 degrees increment.

5. The addition of the slope on the north and south sides shows a considerable decrease compared to the east and west sides. But basically, the value of OTTV on the north and south sides is already lower than the west and east sides. Facade slope up to $20^{\circ}$ on the west side is needed to obtain OTTV values equivalent to the north side in the upright position of $0^{\circ}$ and slope up to $37^{\circ}$ to obtain OTTV values on the south side equivalent of the vertical position of $0^{\circ}$. Whereas for the east side a facade slope up to $7^{\circ}$ is required to obtain an OTTV value equivalent to the north side in an upright position of $0^{\circ}$ and a slope of up to $25^{\circ}$ to obtain an OTTV value equal to the south side in an upright position of $0^{\circ}$ (without being tilted/inclined).

6. Reflective glass calculation results show a decrease in the value of OTTV for all orientations with the addition of the degree of slope of the glass facade.

Slope of The Glass by Rotating the Building The simulation is carried out by rotating the building facades starting from $0^{\circ}, 5^{\circ}, 10^{\circ}, 15^{\circ}$, $20^{\circ}, 25^{\circ}, 30^{\circ}, 35^{\circ}, 40^{\circ}$, and $45^{\circ}$ in a clockwise direction and $0^{\circ}, 5^{\circ}, 10^{\circ}, 15^{\circ}, 20^{\circ}, 25^{\circ}, 30^{\circ}$, $35^{\circ}, 40^{\circ}$, and $45^{\circ}$ counterclockwise, in all four building orientations. The simulation is done using a type of clear glass. The results of OTTV calculations using EnergyPlus are as follows:

- The simulation results rotate the building to the west
Figure 11. The simulation results rotate the building to the west

Source: Author

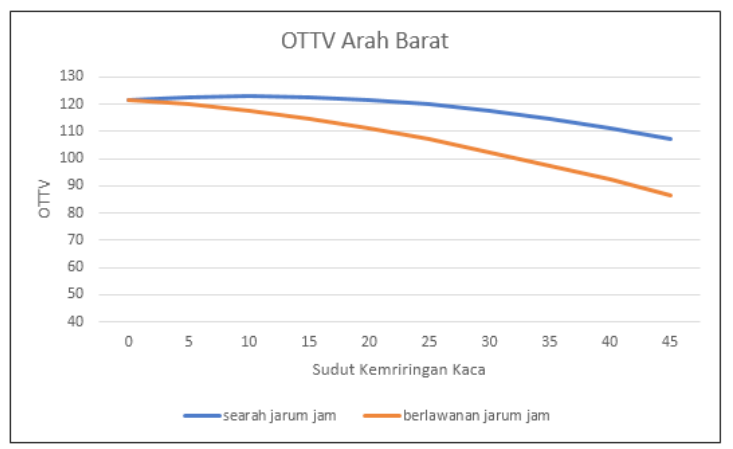

- The simulation results rotate the building to the east

Figure 12. The simulation results rotate the building to the east

Source: Author

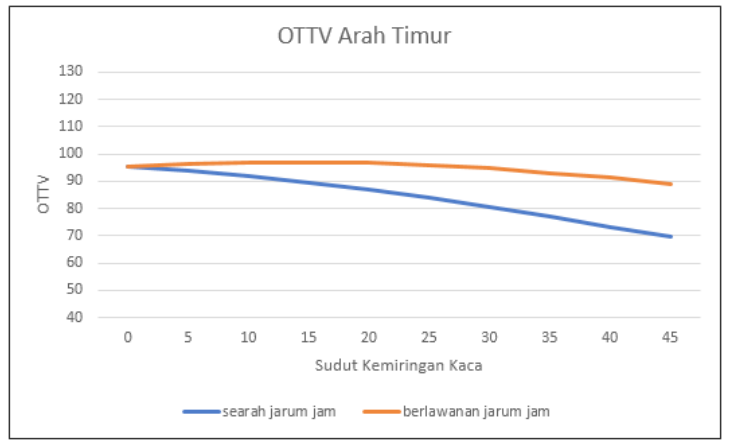

The two pictures above show a decrease in the value of OTTV in the east and west. However, to the west, the OTTV value had increased when tilted clockwise at an angle of $5^{\circ}$ to $1^{\circ}$. Likewise, in the east, which is tilted counterclockwise, there is an increase in the value of OTTV in the first three corners. Both approaches to the north. While the direction approaching the south, there was no increase in the value of OTTV.

- The simulation results rotate the building to the north

Figure 13. The simulation results rotate the building to the north

Source: Author

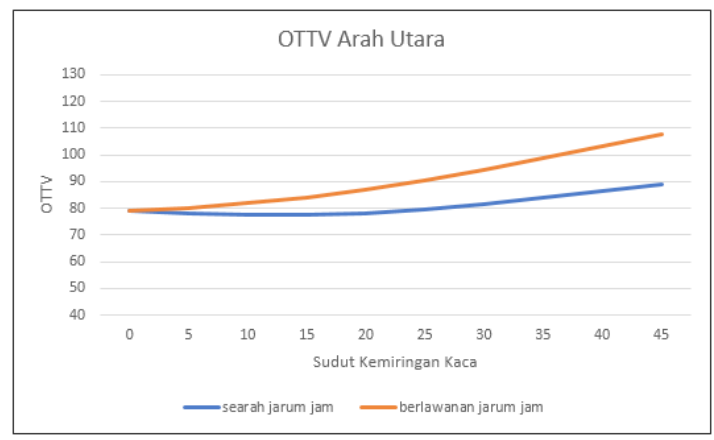


- The simulation results rotate the building to the south

Figure 14. The simulation results rotate the building to the south

Source: Author

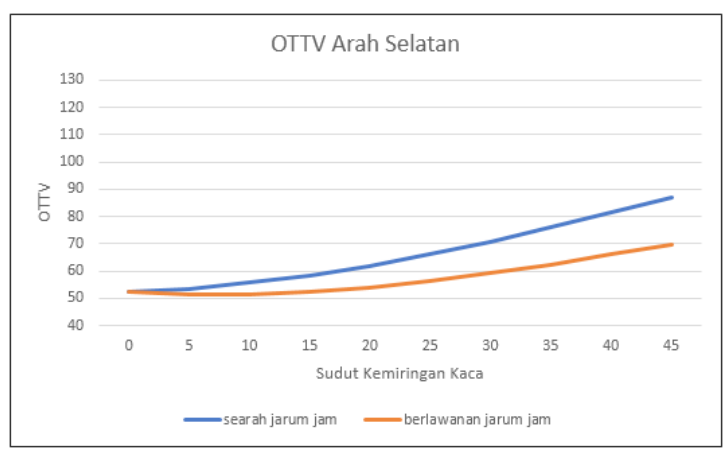

While the two pictures above show the increase in OTTV values in the north and south, both tilted glass in clockwise or counterclockwise show increasing value of OTTV. Both are approaching east and west, where this direction receives the most sunlight. These results are consistent with the results of observations of the optimal glass tilt carried out in India, which leads to the orientation of the South (Gorantla \& Setty, 2015).

\section{Use of Shading in Building Facades Against Impairment of OTTV}

The use of shading also serves to reduce sunlight entering the building through openings. The shading effect also occurs when inclining the surface of the glass against the ground. A hypothetical building OTTV calculation was made with a $90^{\circ}$ tall clear glass that was shaded just above the opening. The length of each shading corresponds to the length of the plenum that formed when inclining the glass surface. Here are the results of a comparison of OTTV calculations between shading and skewed glass.

Figure 15. Comparison of OTTV shading and skewed facades

Source: Author

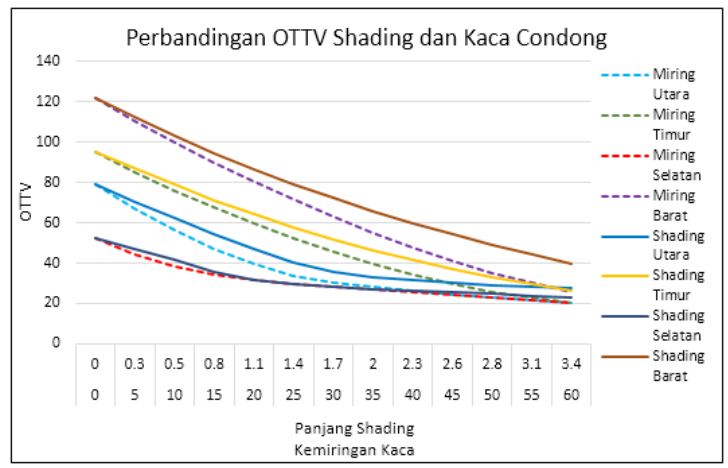

The picture shows a declined OTTV values from all orientations, both from the use of shading or slope of vertical glass. The decrease is directly proportional to the longer the shading and the tilting of the glass. However, the slope of the glass gives a lower OTTV result compared to the installation of shading, especially when the slope of the glass has a more significant angle. Even when the slope of the glass is at an angle of $30^{\circ}$ or when the shading length formed by the plenum is $1.73 \mathrm{~m}$, the OTTV value is almost equal to the OTTV facade value with the $1.73 \mathrm{~m}$ shading along the south side. The north side OTTV value should be higher than the south side (Saud, 2013). This is caused by the north orientation, which is hotter than south obtains sufficient shading by shading formed from the plenum and added to the slope of the glass facade. So the north side OTTV value is low, whereas the orientation of the south has a low OTTV value. So when added to the shading and the sloping glass facade, the resulting decline in the value of OTTV is not so significant. Moreover, the use of shading also requires consideration of costs and maintenance (Kusumawati \& Lahji, 2015).

\section{Conclusion}

To answer the research objective, which is to calculate the effect of the angle of the glass on the value of OTTV in buildings by utilizing the ability of the glass layer in terms of reflecting sunlight, thereby reducing the sun's heat entering the building with the following results:

- Building facades with inclined glass facing the ground are recommended for all orientations and all types of glass because the addition of a tilt angle can reduce the OTTV.

Especially for facades facing west and east, the reduction in OTTV value is proportional to the addition of the tilt angle of the glass. As for the north and south sides, the reduction is only effective up to the angle of the glass $20^{\circ}$ and $15^{\circ}$.

- Rotating the facade horizontally against the ground or rotating the orientation of the building is recommended for facades facing west and east in the direction approaching the south side because the addition of the rotation angle can reduce the value of OTTV. As for the north and south facades, the change of orientation is not necessary, because the addition of the rotation angle 
will only increase the OTTV value.

- It is necessary to replace the type of clear glass with the type of tinted glass or reflective glass to reduce the value of OTTV because the type of tinted glass and reflective glass has a lower OTTV value than the type of clear glass.

- The use of shading for all building orientations affects the impairment of OTTV values in all building orientations. The use of shading in building facades is recommended, especially those with openings because the longer the size of the shading, the value of OTTV decreases.

Tilting and rotating the facade of the building is not the most effective way to reduce the value of building OTTV in Jakarta. This method has little effect in reducing the value of OTTV, especially in the north and south orientations. Regarding the thermal performance of the building envelope, lowering the OTTV value is more effectively done by reducing the WWR and SHGC glass replacement compared to the orientation of the building (Saud, 2013).

\section{References}

Elinur., Priyarsono, D.S., Tambunan, M., \& Firdaus, M. (2010). Perkembangan konsumsi dan penyediaan energi dalam perekonomian indonesia, Indonesian Journal of Agricultural Economics (IJAE).

Groat dan Wang. (2002). Architectural Research Methods. John Wiley \& Sons Inc, USA.

Kirankumar, G., and Setty, A.B.T.P. (2015). Study of optimum inward glass tilt angle for window glass in different indian latitudes to gain minimum heat into buildings. Energy Procedia. V 79

Kusumawati, L, and Lahji, K. (2015). Pengaruh desain fasade terhadap efisiensi energy (The Influence of Façade Design on Energy Efficiency). Seminar Nasional Keberlanjutan Ruang Huni Masa Depan EKO-ARSITEKTUR

Loekita, S. (2006). Analisis konservasi energy melalui selubung bangunan. Civil Engineering Dimension. V8:2

Pereiraa, W., Bögla, A., and Natschlägera, T. (2014). Sensitivity analysis and validation of an EnergyPlus model of a house in Upper Austria. Energy Procidia. V 62

Putri, A. A., Rohman, M. A., and Utomo, C.
(2012). Penilaian Kriteria Green Building pada Gedung Teknik Sipil ITS. Jurnal Teknik ITS, V1:1

Ramadhiani, A. (2017). Sektor Gedung Habiskan 40 Persen Energi Global. Retrieved from: https://properti.kompas. com/read/2017/04/05/230000221/sektor. gedung.habiskan.40.persen.energi.global.

Readitya, D.M.P. (2013), Pengaruh Aplikasi Elemen Pembayangan terhadap Kinerja Termal Selubung Bangunan. Tesis, Program Studi Arsitektur. Universitas Gadjah Mada: Yogyakarta

Saud, M.I. (2013). Pengaruh konfigurasi window to wall ratio, solar heat gain coefficient dan orientasi bangunan terhadap kinerja termal selubung bangunan. Tesis, Program Studi Arsitektur. Universitas Gadjah Mada: Yogyakarta

Sunusi, N.A. (2016). Pengaruh aplikasi elemen pembayang dan kaca terhadap transmisi radiasi matahari direct dan diffuse pada orientasi berbeda. Tesis, Program Studi Arsitektur. Universitas Gadjah Mada: Yogyakarta

Vale, B. \& Vale, R. (1991). Green Architecture: Design for a Sustainable Future. Thames and Hudson Ltd. 